\title{
Temporal and Spatial Patterns in the Prehistoric Settlement of the Lake Bob Sandlin Area, Big Cypress Creek Basin, Northeastern
}

\section{Texas}

Timothy K. Perttula

Heritage Research Center, Stephen F. Austin State University

Bo Nelson

Heritage Research Center, Stephen F. Austin State University

Follow this and additional works at: https://scholarworks.sfasu.edu/ita

Part of the American Material Culture Commons, Archaeological Anthropology Commons, Environmental Studies Commons, Other American Studies Commons, Other Arts and Humanities Commons, Other History of Art, Architecture, and Archaeology Commons, and the United States History Commons

Tell us how this article helped you.

This Article is brought to you for free and open access by the Center for Regional Heritage Research at SFA ScholarWorks. It has been accepted for inclusion in Index of Texas Archaeology: Open Access Gray Literature from the Lone Star State by an authorized editor of SFA ScholarWorks. For more information, please contact cdsscholarworks@sfasu.edu. 
Temporal and Spatial Patterns in the Prehistoric Settlement of the Lake Bob Sandlin Area, Big Cypress Creek Basin, Northeastern Texas

\section{Creative Commons License}

\section{(c) (1) (8)}

This work is licensed under a Creative Commons Attribution-NonCommercial 4.0 International License 


\section{Temporal and Spatial Patterns in the Prehistoric Settlement of the Lake Bob Sandlin Area, Big Cypress Creek Basin, Northeastern Texas}

\section{Timothy K. Perttula and Bo Nelson}

Since many of the archeological sites documented during the course of previous archeological investigations at Lake Bob Sandlin contain temporally diagnostic lithic, ceramic, and/or historic artifacts (Sullivan 1977; Thurmond 1990; Perttula and Nelson 2002; Nelson and Perttula 2003), we have the opportunity to investigate prehistoric temporal and spatial trends in the use of this part of the Big Cypress Creek basin in Northeastern Texas. The discussion of temporal trends in the prehistoric settlement of the Lake Bob Sandlin area is based on the findings from the 108 sites reported by Nelson and Perttula (2003:Table 6), the different components identified by Thurmond (1990) in the 95 sites recorded and investigated in the 1960s and 1970s, and information gained from various prehistoric sites recently recorded at Lake Bob Sandlin State Park (Perttula and Nelson 2002).

From these sites, we have identified 245 prehistoric components in the sample of Lake Bob Sandlin recorded sites. These components testify to the human occupation of this part of the Big Cypress Creek valley since at least 11,500 years ago, when very mobile Clovis hunter-gatherers moved through the area, to the late $17^{\text {th }}$ century A.D. Archeological sites tend to be situated on elevated landforms (including alluvial terraces and uplands) along Big Cypress Creek and its principal tributaries in the lake area, including Brushy Creek, Blundell Creek, Jakes Creek, Andys Creek, Picket Spring Branch, and Camp Branch (Figure 1).

In prehistoric times, the most intensive settlement of the Lake Bob Sandlin area occurred between ca. A.D. 1200-1680 (Table 1), when Caddo Indian farmers lived in numerous farmsteads, hamlets, and villages along

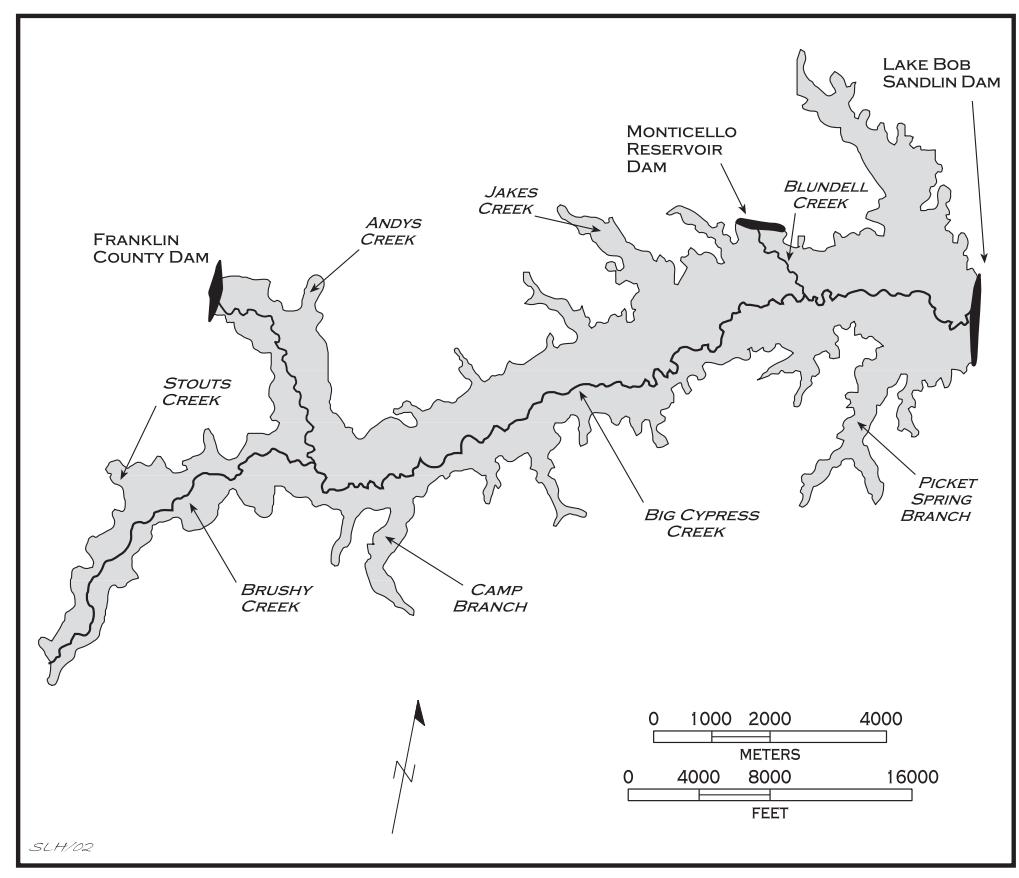

Figure 1. Major dranages at Lake Bob Sandlin. many of the streams and sandy landforms in the valley. There were many Late Archaic occupations in the lake area, but these were not permanent settlements, but temporary and seasonal encampments of hunter-gatherers. Nevertheless, foraging activities, and the spatially expansive use of different habitats (see below) during the Late Archaic period clearly contrasts to the much lower use of the Lake Bob Sandlin area during the Paleoindian and Early to Middle Archaic periods (see Table 1).

The temporal interval between the end of the Late Archaic period and the beginning of the Middle Caddo period-from ca. 500 B.C. to A.D. 1200 - was one of apparent lesser use, 
Table 1. Temporal Differences in Prehistoric Settlement Intensity at Lake Bob Sandlin.

\begin{tabular}{|c|c|c|}
\hline Periods & $\begin{array}{l}\text { No. of Identified } \\
\text { Components }\end{array}$ & Components per 100 Years \\
\hline Paleoindian & 16 & 0.53 \\
\hline Early Archaic & 15 & 0.50 \\
\hline Middle Archaic & 25 & 1.25 \\
\hline Late Archaic & 80 & 5.33 \\
\hline Woodland & 29 & 2.15 \\
\hline Early Caddo & 17 & 4.25 \\
\hline Middle Caddo & 22 & 11.00 \\
\hline Late Caddo & 41 & 14.64 \\
\hline
\end{tabular}

Sources: Thurmond (1990); Perttula and Nelson (2002); Nelson and Perttula (2003)

given the relatively low number of components per 100 years (see Table 1). However, this may be misleading, for two reasons that immediately come to mind. The first is that the archeological recognition of Woodland and Early Caddo components is difficult to make without the recovery of numerous temporal diagnostics (projectile points and/or ceramics) and/or by obtaining absolute radiocarbon dates from these components. Second, if these prehistoric Caddo peoples were becoming more sedentary during these periods, then we would expect fewer components per 100 years then we would when compared to the more mobile Late Archaic groups that inhabited the area before them.

But if we assume, for the purposes of this discussion, that the Woodland and Early Caddo groups living at Lake Bob Sandlin were more sedentary, and probably by the Early Caddo period lived in small dispersed homesteads and hamlets, then the more apt comparisons of temporal trends in settlement intensity are between the Woodland and Early Caddo periods-with 2.15-4.25 components per 100 years—and the immediately following Middle and Late Caddo periods. During these times, the frequency of components per 100 years is at least 2-6 times higher than it was between 500 B.C. and A.D. 1200.

With the archeological information available to us of both prehistoric and historic sites from the Lake Bob Sandlin area, it is apparent that there was a ca. 150 year period from 1680-1830 when this part of the Big Cypress Creek basin was abandoned. Perhaps the major factor that contributed to this abandonment was that the Caddo groups living here were exposed to introduced European epidemic diseases by the late $17^{\text {th }}$ century that they were not immune to, and these groups either died off, or the survivors moved away to join other surviving Caddo groups along the Red River, in the upper Sabine River basin, or in the Neches-Angelina river basin. Small numbers of Caddo Indians probably continued to live in certain parts of the Big Cypress Creek basin in the $18^{\text {th }}$ century - based on a very few number of Caddo Indian sites that have been reported to contain European trade goods - but no such sites have been found or reported in the upper part of the Big Cypress Creek basin.

The prehistoric and historic archeological sites at Lake Bob Sandlin are widely distributed throughout the Big Cypress Creek alluvial valley and the valleys of its several tributaries, the principal tributary being Brushy Creek at the western and upper end of the lake (see Figure 1). The spatial distribution of these sites, in conjunction with the identification of archeological components as well as the temporal trends discussed above, may provide additional insights on the prehistoric settlement of this part of Northeast Texas. 


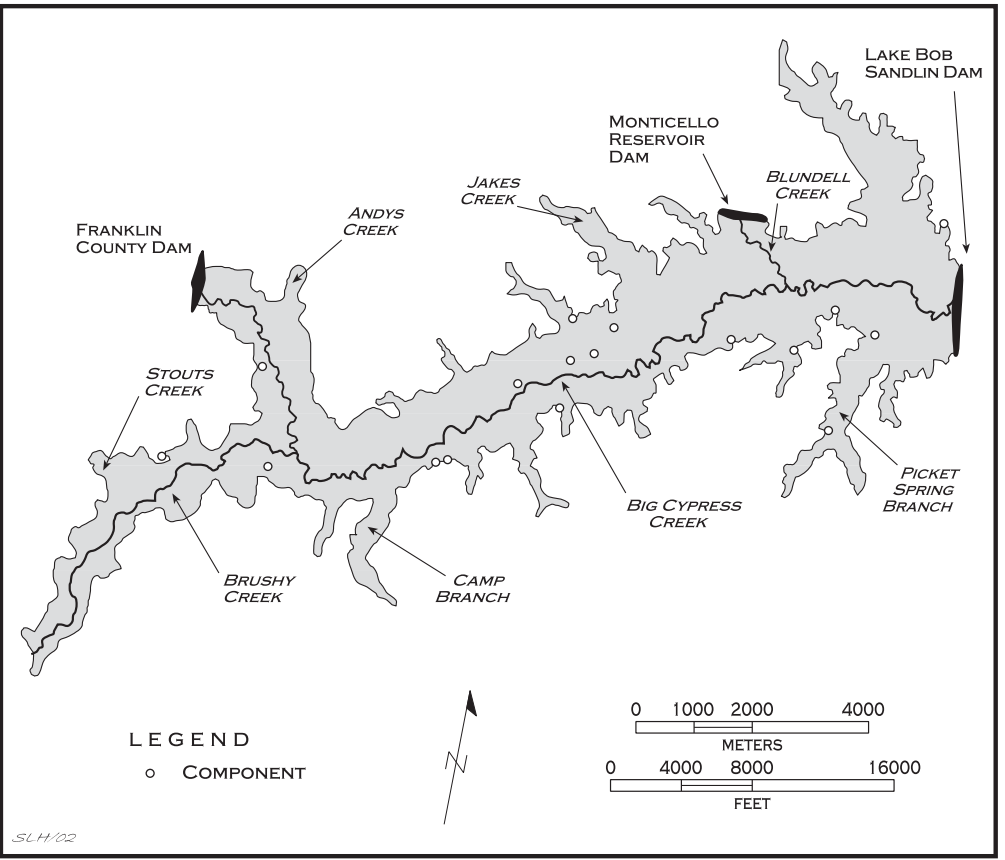

Figure 2. Distribution of Paleoindian components at Lake Bob Sandlin.

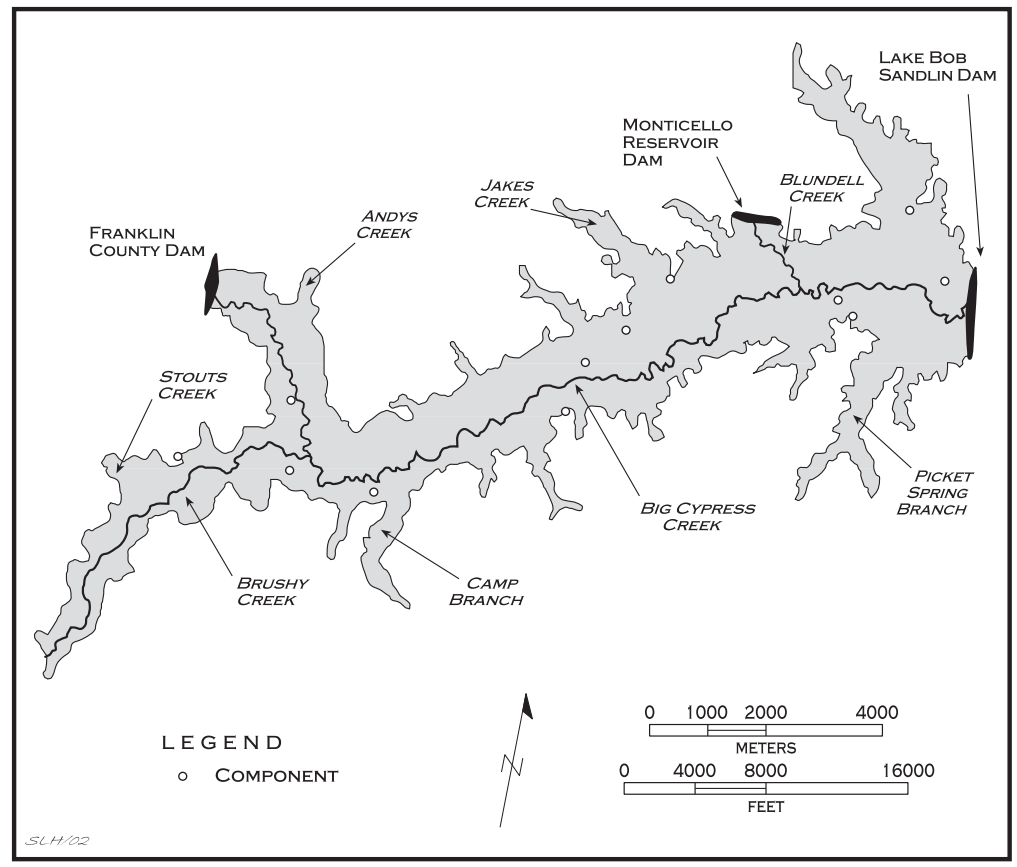

Figure 3. Distribution of Early Archaic components at Lake Bob Sandlin.
Paleoindian, Early Archaic, and Middle Archaic sites are found almost exclusively in the Big Cypress Creek and Brushy Creek valleys, situated either on stable Pleistocene terrace landforms or on upland crests and slopes overlooking the alluvial valleys (Figures 2-4). These are the kinds of stable and elevated landforms that would still preserve today some evidence of these earlier occupations, and there may well be buried Paleoindian-Middle Archaic sites in the basal levels of now-submerged alluvial terraces that were accumulating from the latter part of the Pleistocene period (ca. 11,000 years ago) through the Middle Archaic era. Of course, such sites and landforms are not readily accessible for further study because they are submerged. It is also possible that these earlier prehistoric sites may have been present in some numbers along the smaller tributaries (and in fact, one Middle Archaic component has been identified on Camp Branch, see Figure 4), but more recent erosional episodes would have removed any deposits of Paleoindian to Middle Archaic age.

Given these caveats, it does appear to be the case that settlements during Paleoindian, Early Archaic, and Middle Archaic times focused on the plant and animal-rich resources to be found in higher densities in the Big Cypress Creek and Brushy Creek alluvial valleys than along the smaller streams. The upland habitats that were chosen for settlement usually immediately overlooked the valleys, either be-

cause of their suitability for tracking game, and/or because other important resources could be obtained there, including knappable lithics, and plant mast, especially oak and hickory nuts. Only in Middle Archaic times do we begin to detect a clustering of different settlements-in the Big Cypress Creek valley immediately upstream of its confluence with Picket Spring Branch, and near the confluence of Jakes Creek with Big Cypress Creek (see Figure 4) — that hint at the most preferred locations for settlements and encampments by Middle Archaic peoples. 
During Late Archaic times, settlements are very widely dispersed across the landscape, with many sites on alluvial landforms near the major streams-which flowed year-roundbut just as many Late Archaic sites are in the uplands and along the smaller spring-fed branches (Figure 5). This spatial distribution suggests that during Late Archaic times, seasonal or multi-seasonal encampments were located wherever there were economically viable plant and animal resources to procure, regardless of the season, and that a respectable proportion of those resources could be obtained outside of the environmentally-rich creek valleys. By Late Archaic times, a more or less modern environmental setting had

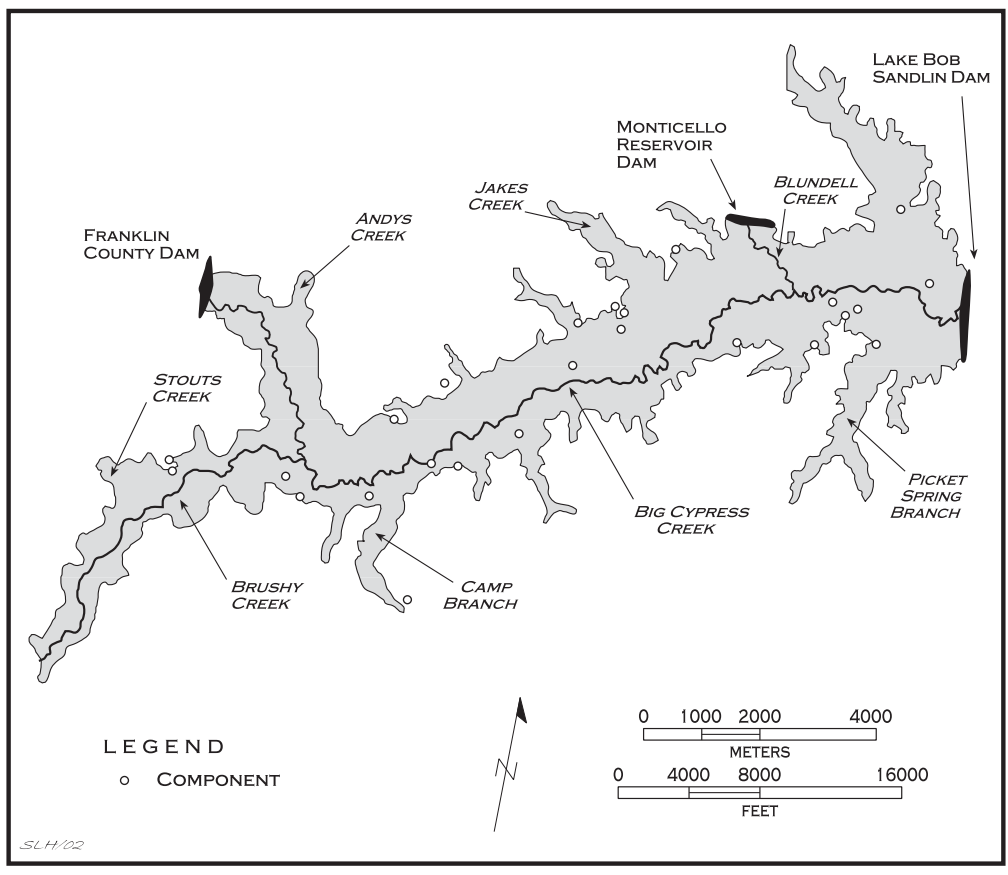

Figure 4. Distribution of Middle Archaic components at Lake Bob Sandlin. been established in Northeast Texas and the Big Cypress Creek basin (see Perttula 2003), and the uplands would have been forested with a mixture of hardwoods and pine trees, with more pine trees along the southern side of the Big Cypress Creek valley, but hardwood nuts and a variety of animal species would have been present on the floodplain and terrace landforms as well as the wooded slopes and upland crests. Many small springs on both sides of the valley would also have been flowing at this time, and the combination of abundant water, and an equitable climate

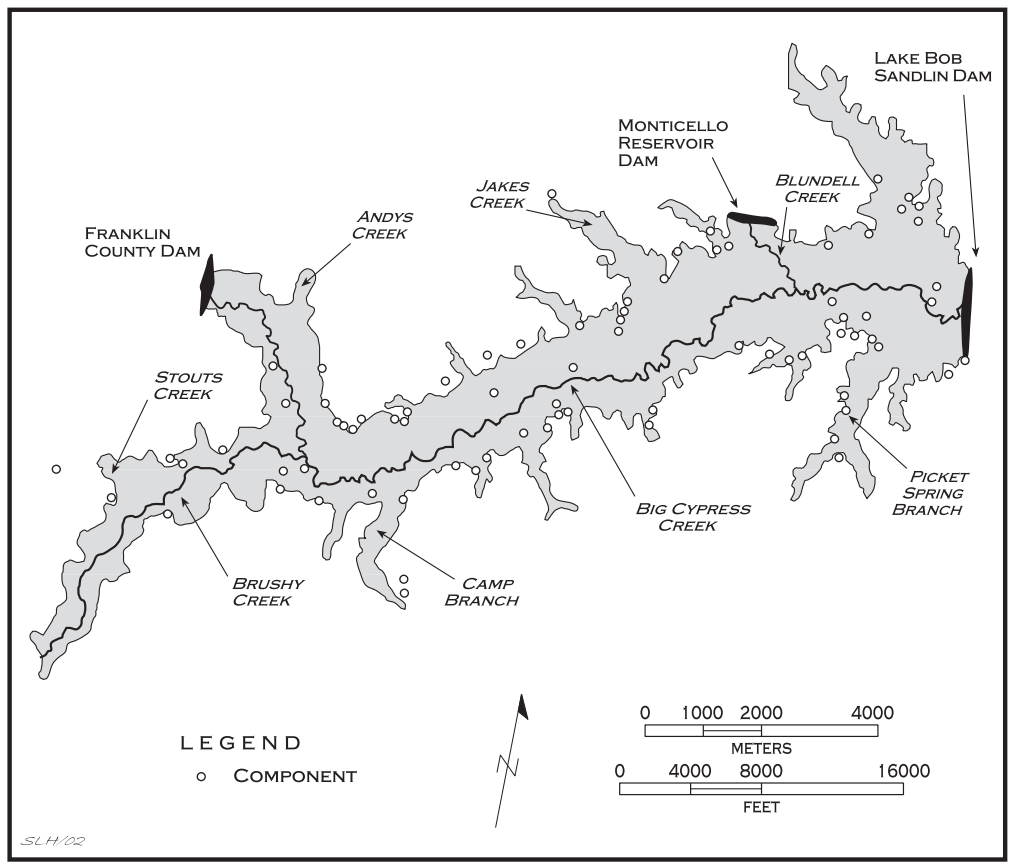

Figure 5. Distribution of Late Archaic components at Lake Bob Sandlin. and temperature regime, means that the overall carrying capacity of local habitats in the Big Cypress Creek basin would have been much higher in the Late Archaic than was the case during the Early and Middle Archaic periods. For a mobile hunting-gathering population that depended upon the plant and animal products of the forest, climatic conditions during the Late Archaic period would have been optimal in the long-term. We think this is reflected in the wide distribution of such sites and the frequency of Late Archaic components at Lake Bob Sandlin.

Late Archaic components tend to be located on landforms that occur in proximity to-or easy movement between-both floodplain and upland 


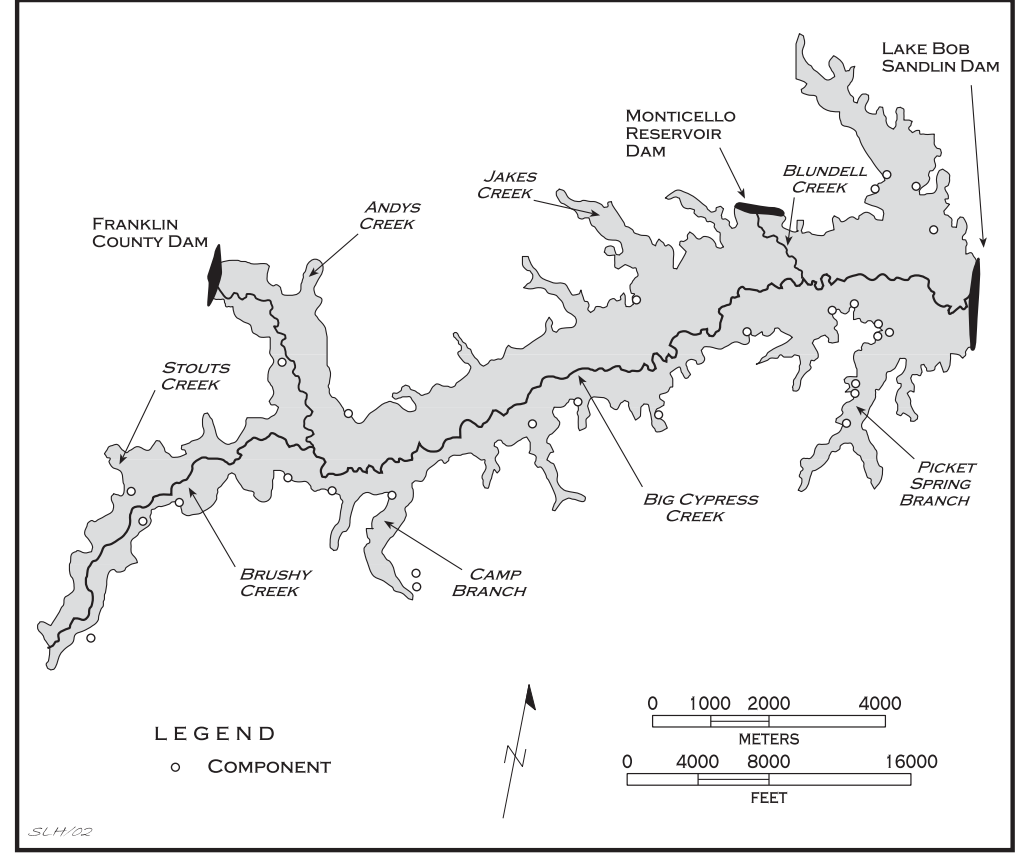

Figure 6. Distribution of Woodland period components at Lake Bob Sandlin. resources. Such settings seem to be near the confluence of smaller creeks and spring-fed branches with Big $\mathrm{Cy}$ press Creek (see Figure 5).

There are not many identifiable Woodland period components at Lake Bob Sandlin (see Table 1). They are found along the valley margin on elevated landforms, particularly upland slopes and toe slopes, and are notably more common along the secondary streams (such as Picket Spring Branch, Camp Branch, and Brushy Creek, as well as intermittent streams) than during the Paleoindian or Archaic eras (Figure 6).

None of the Woodland period sites are especially large in size or have midden deposits, and we think it is unlikely that these settlements were occupied by either a large number of people or for lengthy periods of time. Their distribution suggests that the resources found along the secondary streams were of some particular importance, and such resources could include wild plants and animals as well as arable tracts of soil for the ready manipulation and cultivation of seedy annuals, squash, gourds, and perhaps even a little maize during the latter part of the Woodland period (after ca. A.D. 700). Sources of fresh water may have been more dependable on the smaller streams, and this was attractive for ancestral Caddo populations. There are two notable concentrations of Woodland period sites at Lake Bob Sandlin: (1) along and at the mouth of Picket Spring Branch, and also overlooking the Big Cypress Creek valley; and (2) near the mouth of a larger unnamed tributary on the north side of the Big Cypress Creek valley, directly across from the Picket Spring Branch cluster (see Figure 6).

The Early and Middle Caddo sites and components have comparable spatial distributions across Lake Bob Sandlin (Figures 7 and 8). The components are widely spaced across the lake area, but occur primarily along Big Cypress Creek and Brushy Creek. Components outside of the main stream valley can be found on Camp Branch and Stouts Creek, as well as the unnamed tributary on the north side of the valley near the Lake Bob Sandlin dam. The few such settlement locations principally date to the Middle Caddo period, and may presage the much more significant use of uplands and tributary streams during the Late Caddo period (see below).

Archeological evidence from Lake Bob Sandlin sites, and other sites investigated elsewhere in the Big Cypress Creek basin, indicate that many of the Early and Middle Caddo components here represent permanent, year-round, settlements of horticultural peoples. The locations that they chose to permanently settle and build structures and other facilities at had to be situated in habitats where suitable sandy soils were nearby that could be worked with simple wood and bone digging tools, and that the land they built their homesteads and communities on had to be well-drained and elevated above the annual floods along Big Cypress Creek and its tributaries. They also had to be in areas where wood and grass was plentiful for house construction and 
refurbishing, as well as near fresh drinking water. The fact that the Early and Middle Caddo settlements are not found in any notable spatial clusters within the lake area (except perhaps for one cluster of Early Caddo components along the edge of the Big Cypress Creek alluvial valley and west of its confluence with Camp Branch, see Figure 7) suggests that the many resources that were needed by sedentary Caddo populations to successfully live in the Big Cypress Creek valley could best be exploited by dispersing the groups in a variety of settings.

This dispersed settlement arrangement would help lessen the competition for such resources, and not allow for the environmental degradation of suitable habitats by a single large community. It would also permit the Caddo peoples to take advantage of the diversity in habitats to exploit a number of them, thus insuring that the overall community could survive if there were economic difficulties or failures (i.e., local droughts, flooding, fires) in some habitats but not in most of the others.

In Late Caddo times, when the Caddo peoples had a diet that primarily consisted of cultivated plants like maize, beans, and squash, agricultural pursuits must have been of particular importance in determining the location of individual farmsteads and hamlets, more so than they were in the Early or Middle Caddo periods.

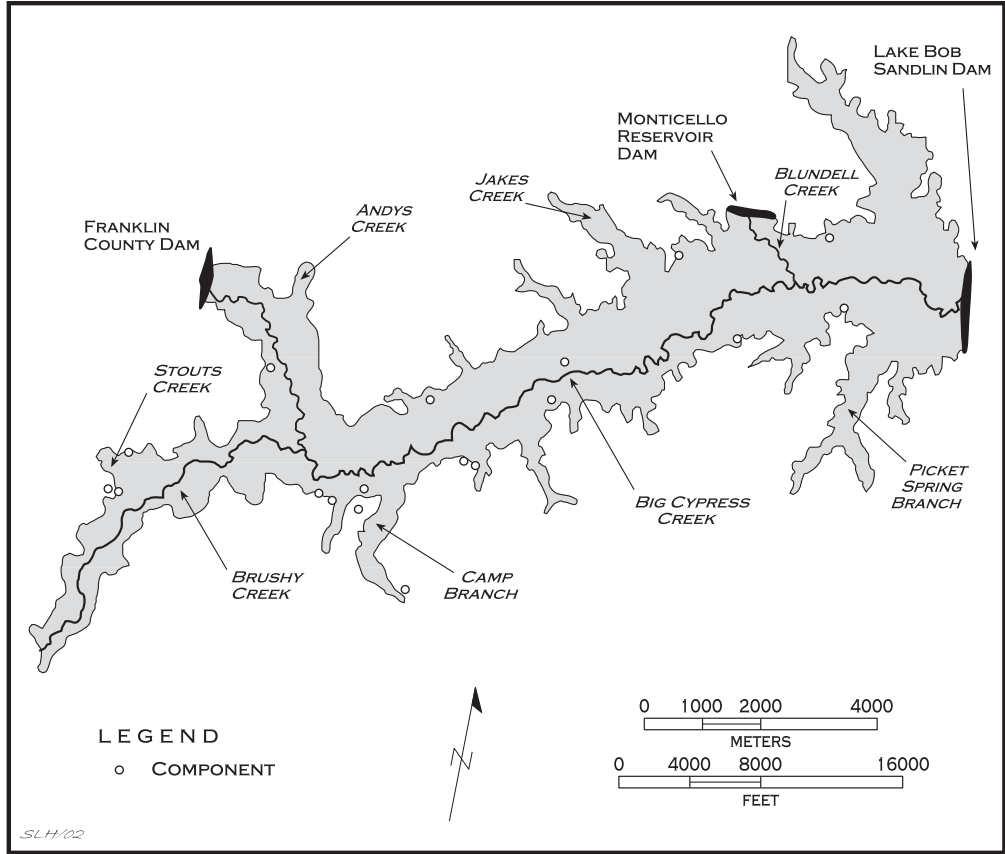

Figure 7. Distribution of Early Caddo period components at Lake Bob Sandlin.

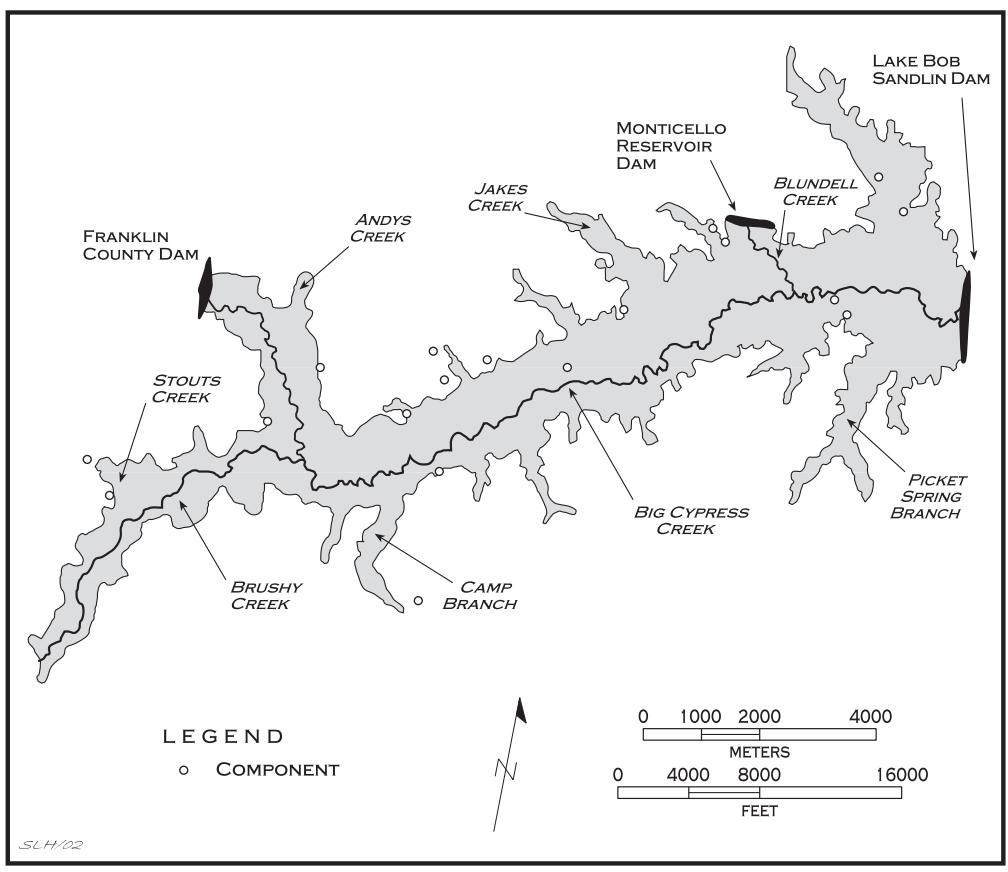

Figure 8. Distribution of Middle Caddo period components at Lake Bob Sandlin. How are these constraints reflected in the spatial distribution of Late Caddo sites? What we see is that the overall settlement pattern was dispersed (Figure 9), in conjunction with a heightened emphasis on situating sites along the secondary streams and the spring-fed branches. These areas may have had more dependable water, or more accessible water, and it is also likely that fields would have been easier to clear along the more open upland forests than if fields had to be located in the more mesic valleys. 
There are more Late Caddo sites than sites found during earlier periods, suggesting that the regional population was quite a bit higher during the Late Caddo period (all things being equal, especially the length of time each settlement was occupied), and there are several clusters of settlements that may represent parts of contemporaneous small communities or villages. One such cluster-and probably the most important one in the valley since one site in the cluster (Lower Peach Orchard, 41CP17) had a number of deep shaft tombs as well as extensive settlement deposits (Thurmond 1990; Perttula 1998)—occurred along Big Cypress Creek and Picket Spring Branch (see Figure 9). Others are noted along Brushy Creek upstream from its confluence with Big Cypress Creek, and in upland/valley margin settings.

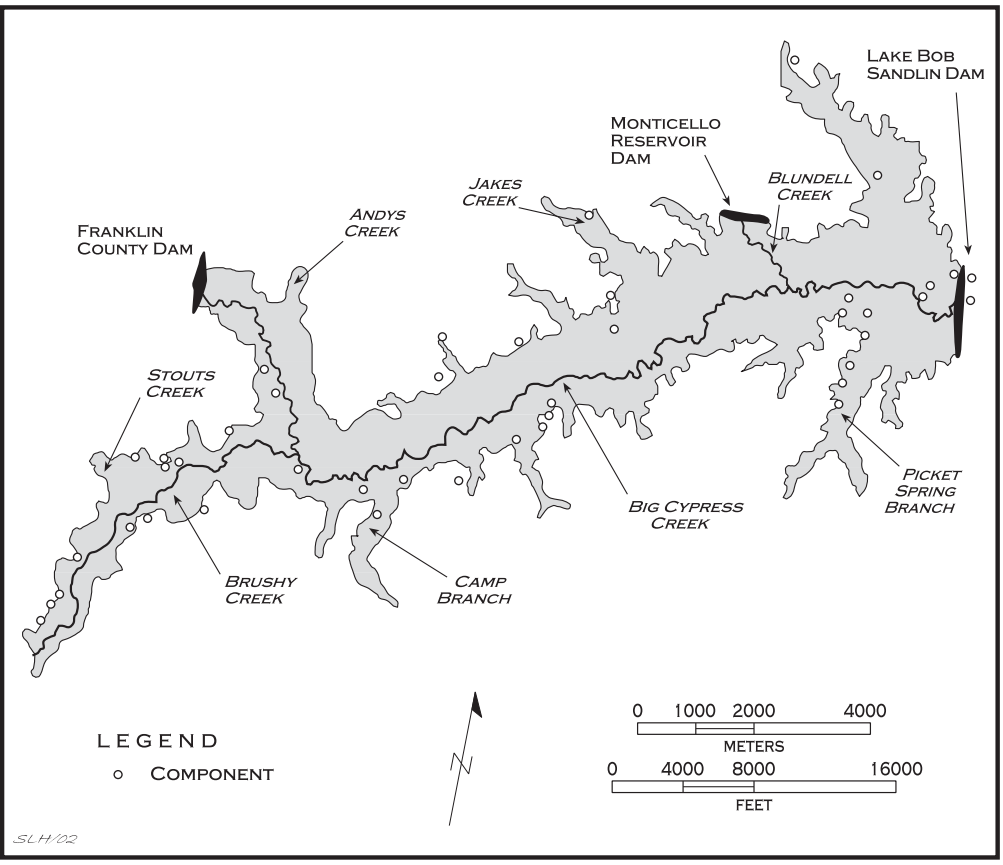

Figure 9. Distribution of Late Caddo period components at Lake Bob Sandlin.
We do note that Late Caddo sites are more common south of Big Cypress Creek than they are on the Titus County or north side of Lake Bob Sandlin. Regional settlement data for the Titus phase does suggest that this pattern in the spatial distribution of sites at the lake may be part of a much broader trend in the density of Late Caddo sites between the Titus phase "heartland" and outlying areas (see Perttula 1998, 2003). That trend indicates that Titus phase sites-as well as Titus phase sites with mounds and large community cemeteries-are more common across the landscape from the Lake Bob Sandlin dam area downstream along Big Cypress Creek than they are in the Post Oak Savannah immediately north and northeast of Big Cypress Creek.

\section{REFERENCES CITED}

Nelson, B. and T. K. Perttula

2003 Archeological Survey along the Lake Bob Sandlin Shoreline, Camp, Franklin, and Titus Counties, Texas. Report of Investigations No. 46. Archeological \& Environmental Consultants, LLC, Austin.

Perttula, T. K.

1998 Late Caddoan Societies in the Northeast Texas Pineywoods. In Caddoan Native History: Their Place in Southeastern Archeology and Ethnohistory, edited by T. K. Perttula and J. E. Bruseth, pp. 69-90. Studies in Archeology 30. Texas Archeological Research Laboratory, The University of Texas at Austin.

2003 The Prehistoric and Caddoan Archeology of the Pineywoods and Post Oak Savannah of Northeast Texas. In The Prehistoric Archeology of Texas, edited by T. K. Perttula. Texas A\&M University Press, College Station, in press.

Perttula, T. K. and B. Nelson

2002 Archeological Survey of Lake Bob Sandlin State Park, Titus County, Texas. Report of Investigations No. 48. Archeological and Environmental Consultants, Austin. 
Sullivan, T. L.

1977 Archaeological Investigations at Lake Bob Sandlin, Texas. Research Report 99. Archaeology Research Program, Southern Methodist University, Dallas.

Thurmond, J. P.

1990 Archeology of the Cypress Creek Drainage Basin, Northeastern Texas and Northwestern Louisiana. Studies in Archeology 5. Texas Archeological Research Laboratory, The University of Texas at Austin. 